\title{
"Just because you don't see your boss, doesn't mean you don't have a boss": COVID-19 and Gig Worker Strikes across Latin America
}

By Kelle Howson, Funda Ustek-Spilda, Rafael Grohmann, Nancy Salem, Rodrigo Carelli, Daniel Abs, Julice Salvagni, Mark Graham, Maria Belen Balbornoz, Henry Chavez, Arturo Arriagada, and Macarena Bonhomme

\section{Introduction}

Latin America has been hit hard by COVID-19. On 22 September, the region had reported more than 8.8 million cases, and 325,000 deaths (Horton, 2020). As daily case numbers began to fall in Europe from May onwards, they continued to surge in Brazil, Argentina, Colombia, Mexico and across the region. So far, Brazil has recorded the third highest number of cases in the world, 4.5 million as at September, and more than 140,000 people have lost their lives.

Looking beyond the headline numbers, it is clear that the region's high levels of inequality have shaped the course and the outcomes of its pandemic experience. Latin America includes some of the most unequal countries in the world, and these existing inequalities inevitably put the greatest pressure on those on the margins of the labour market. 'Gig' (or 'platform') workers, who perform piece-rate on-demand tasks through apps, have been particularly hard hit. Many gig workers lost their incomes overnight as a result of lockdowns, while others risk heightened exposure to the virus in order to keep earning.

While the images of mass grave sites dominated news emanating from Latin America in May, weeks later another story of global significance was emerging - large, coordinated strikes by gig economy workers across the region. As early as April, workers had begun striking against dangerous working conditions and low pay during the pandemic. Protests intensified in July, with large-scale strikes on July 1 spanning ten Brazilian cities, alongside other countries, including Argentina, Ecuador, Chile and Mexico. Further international strikes occurred in August. The strikers were food delivery couriers, working for Uber Eats, Rappi, iFood, Glovo and other platforms.

These strikes are particularly historic, in that they represent the first real example of an international, sector-wide, strike movement in the gig economy. They have been catalysed by the conditions of the pandemic for a number of reasons. COVID-19 has further eroded gig workers' already tenuous financial and physical security, whilst also demonstrating the essential nature of the work they perform. These conditions highlight the core issue of the misclassification of platform workers as independent contractors without access to employment rights or benefits. As the struggle faced by gig workers in Latin America has only intensified, the pandemic has provided the impetus and platform for thousands to raise their voices against underlying structural injustices.

In this article, we trace the courier strikes across Latin America, with evidence from Brazil, Chile and Ecuador from April to August. These case studies have been compiled by researchers in the Fairwork network, a multi-national collaborative research project that tracks labour conditions in the gig economy, and encourages labour platforms to meet defined standards of fair work in the absence of regulation (Graham et. al., 2020). 


\section{COVID-19 and Worker Strikes Across Latin America}

Histories of profound social inequality mean precarious working conditions are already normalised in many Latin American countries, however so are legacies of labour resistance. In Brazil, many have worked in insecure jobs, as couriers, cleaners and drivers, for a long time before the advent of digital labour platforms. Nevertheless recent years have witnessed the further erosion of public provision of social security, education, health, and labour rights, paving the way for the gig economy model of algorithmically-managed insecure work to become widespread. As President Jair Bolsonaro pronounced early in his term; "workers will have to choose between more rights or more jobs" (in Araujo \& Murakawa, 2020).

COVID-19 has further heightened the precarity faced by gig workers (Fairwork, 2020). In the gig economy, workers disproportionately bear both the risks, and the costs associated with the labour process (Fredman et. al., 2020). For delivery drivers, the risk of contracting the virus is now added to the ever-present risk of road accidents. Additionally, restaurant closures have increased the risk of non-payment, and deactivation. At the centre of this issue is the practice of classifying workers as independent contractors. Because gig workers are not classified as employees, platforms are not held responsible for the dangers they face in their work. This has seen platform workers largely barred from the safety net that formal employees have counted on during the pandemic. Ineligible for social protections and operating outside labour regulation, they seldom have the option of not logging in to work, even whilst others shelter at home (Bonhomme, Arriagada \& Ibáñez, 2020).

Platforms have failed to protect workers in this regulatory vaccum. Instead, they have presided over deteriorating working conditions, with some even profiteering from the crisis at workers' expense. A sharp rise in demand for food and grocery delivery has been documented in lockdowns across the world (Butler, 2020; Clark, 2020; Gladman, 2020). In Brazil, the number of food orders through platforms increased by 77 percent in March and April (Larghi, 2020). Research has revealed that food delivery couriers are working harder but earning less than they used to, as gig workers' ranks swell with the wave of newly unemployed (Abilio et. al., 2020). Moreover, costs associated with gig work have also increased, forcing workers to be online for longer hours. One union in Brazil recently estimated that drivers earned on average USD1.15 to 1.91 per hour, and worked between 10 and 12 hours a day (Pskowski \& Vilela, 2020). Strikers have strongly refuted platforms' claims that they are being provided with personal protective equipment (PPE).

Glovo and Rappi workers leading the strikes in Ecuador also cited a lack of PPE as one of their greatest concerns. However, their most pressing demand has been about decreasing pay. With justifications of social solidarity and doing their bit to support the Covid-19 response, platforms in Ecuador have reduced delivery commissions for riders.

In Chile it has been a similar story. Changes in payment have led to widespread discontent amongst workers. Here too, despite platforms' assurances, workers have battled to access PPE. One driver, Andres, reported that despite receiving numerous instructions on protecting consumers, (e.g. keeping a distance of two meters, and washing his hands with alcohol gel), none of the platforms he works for have given him masks or gloves, even though his work involves queuing in busy 
supermarkets (Bonhomme, Arriagada \& Ibáñez, 2020). As part of the strike action in Chile, a group of 19 mostly migrant workers, filed two labour complaints against Pedidos $\mathrm{Ya}$, demanding to be recognised as employees, and accusing the platform of having fired them without justification or due process. Workers have also encountered convoluted appeals processes, having to navigate limited options for communicating grievances with platform management.

Left with little or no ability to change their circumstances, workers have turned to social media as a ground-up tool to bring their struggle to the fore and solicit public and consumer support. At the centre of the strikes in Brazil was the "Anti-Fascist Couriers" movement, led by food delivery driver Paulo Galo. Galo's social media messages became rallying cries, including through a viral video posted in March, in which he asked app users, "Do you know what torture it is to go hungry while I am carrying your food on my back?"

Disseminated through popular social media platforms such as Twitter, Facebook, Instagram, and WhatsApp, Galo's messages offered a powerful reference point for the aims of the collective action. In defiance of the narrative propagated by platforms, that gig workers are independent contractors, Galo told fellow workers: "We are not entrepreneurs", and "Just because you don't see your boss, doesn't mean you don't have a boss". Through the hashtag \#BrequeDosApps, or \#StopTheApps, Brazilian strikers appealed to consumers to show solidarity by not ordering anything through the platforms during the action (Pskowski \& Vilela, 2020). Workers in Chile were similarly able to organise via social media, in particular through the Twitter account "Riders Unidos Ya", referring to the platform Pedidos Ya.

Organising via social media has allowed the strikes to occur across countries, targeting multiple companies in the sector. There has been a wide diversity of perspectives represented in the strikes and in digital spaces where workers organise. Despite some disagreements between workers' organisations, the common experience of the pandemic has spurred workers to unite behind common demands for improved conditions in the gig economy. This emphasises the possibilities for a fairer future of digital work; in which social media platforms can facilitate worker empowerment. In one example of the ground-up pursuit of a fairer platform economy, one group is building a workers' cooperative platform, Despatronados (meaning 'without boss'), already in beta version.

\section{Discussion}

The full extent of the devastation wrought by COVID-19 will not be known for some time. However, it is clear that it has placed immeasurable pressure on already precarious workers, and laid bare the contradictions and unsustainability of the current gig economy model. So far, this model has succeeded in suppressing collective worker action by misclassifying dependent workers as independent contractors, and therefore ensuring they are atomised, isolated, and face higher barriers to asserting their rights. However, the widespread disruption of COVID has pushed this situation to its extreme and made it more visible, in Latin America and elsewhere. The pressures of the pandemic have become an impetus for labour resistance.

Strikes have of course occurred with some regularity in the global gig economy, prior to and during the pandemic. However, the delivery drivers' uprising in Latin America is noteworthy for several 
reasons, the foremost being its scope and scale. These strikes have been coordinated across multiple countries, and coalesced around clearly articulated shared demands. They have targeted all the major operators in a sector simultaneously. These developments offer renewed hope for a sustained labour resistance and a fairer future of platform work. Cross-border action is all the more important in the gig economy context, as platforms have strategically positioned themselves as transnational and disembedded, partly in an attempt to evade regulation and responsibility (Katta et. al., 2020; Cant, 2019).

The scale of this action has been facilitated by digital connectivity, even whilst aspects of digitalisation are what is being resisted. The movement has been propelled through social media, by powerful messaging from workers themselves. These messages have cut to the core of platforms' sustaining narratives, especially that of workers as entrepreneurs. As the public has become increasingly aware of the essential nature of the tasks performed by gig workers - crucial to the pandemic response - workers have seized this moment to appeal to consumers for support in their struggle. Platforms continue to go to lengths to distance themselves from responsibility for working conditions, but the widespread strikes in Latin America represent an unprecedented challenge to this status quo.

\section{References}

Abilio, L, et. al. (2020). Condições de trabalho de entregadores via plataforma digital durante a COVID-19. Revista Jurídica Trabalho e Desenvolvimento Humano 3.

Araujo, C. \& Murakawa, F. (2018, 4 December). Bolsonaro: Trabalhador terá de escolher entre mais direitos ou emprego. Valor.

Butler, S. (2020, 10 March). Delivery and Digital Services Thrive on Coronavirus Outbreak. The Guardian.

Bonhomme, M., Arriagada, A., \& Ibáñez, F. (2020, 4 April). La otra primera línea: COVID-19 y trabajadores de plataformas digitales. Cipher.

Cant, C. (2019). Riding for Deliveroo: resistance in the new economy. John Wiley \& Sons.

Clark, E. (2020, August 26). Grocery Store Trends: Why Delivery Dominates Supermarket News. The Manifest.

Fairwork. (2020). The Gig Economy and Covid-19: Looking Ahead. Oxford, United Kingdom.

Fredman, S., du Toit, D., Graham, M., Howson, K., Heeks, R., van Belle, J-P., Mungai, P. \& Osiki, A. (2020). Thinking Out of the Box: Fair Work for Platform Workers, King's Law Journal, 31:2, 236-249

Gladman, R. (2020, August 7). Takeaways back in Growth following Coronavirus Shock. ADHB.

Graham, M., Woodcock, J., Heeks, R., Mungai, P., Van Belle, J. P., du Toit, D., ... \& Silberman, S. M. (2020). The Fairwork Foundation: Strategies for improving platform work in a global context. Geoforum.

Horton, J. (2020, 24 September). Coronavirus: What are the numbers out of Latin America?. BBC. 
Katta, S., Badger, A., Graham, M., Howson, K., Ustek-Spilda, F., \& Bertolini, A. (2020). (Dis) embeddedness and (de) commodification: COVID-19, Uber, and the unravelling logics of the gig economy. Dialogues in Human Geography, 10(2), 203-207.

Larghi, N. (2020, 2 April). Com quarentena, apps de entregas são oportunidade para trabalhadores e comércios'. Valor Investe

Pskowski, M \& Vilela, R. (2020, August 12). 'They Aren't Anything Without Us': Gig Workers Are Striking Throughout Latin America, Motherboard. 